\title{
SUSTAINABLE FINANCE AND BANKING: A CHALLENGE FOR REGULATORS AND A RISK MANAGEMENT SYSTEM
}

\author{
UDC $336+336.71$
}

\section{Mirjana Jemović, Jelena Radojičić}

University of Niš, Faculty of Economics, Serbia

ORCID iD: Mirjana Jemović $\quad$ (i) https://orcid.org/0000-0002-5212-182X Jelena Radojičić (ㄷ) https://orcid.org/0000-0003-3444-0138

\begin{abstract}
The key position of banks in the financial sector, as well as their indisputable role in financing economic development, have conditioned the need to consider their impact on the environment. The implementation of the concept of sustainability in banking has conditioned the transformation of banks in the direction of their greater corporate eco-efficiency and the development of banking products and services that contribute to sustainable development. Sustainable finance for banks is a source of new opportunities, but on the other hand, banks are more and more concerned about their exposure to environmental risk. Recognizing the impact of environmental risks on banks' operations, central banks and supervisors are taking a number of initiatives to reduce the negative impact of these risks on banks' operations, and, thus, financial stability. The paper aims to point out the challenges that sustainable banking has posed to regulators and the risk management system.
\end{abstract}

Key words: sustainable banking, environmental risks, regulation

JEL Classification: G21, G28, Q56

\section{INTRODUCTION}

Preservation of health and protection of natural resources have created the need to balance the relationship between ecology, economic development and natural resources, which has resulted in the promotion of the concept of sustainable development. This concept should make it possible to meet the needs of present generations without compromising the

Received June 09, 2021 / Accepted July 14, 2021

Corresponding author: Mirjana Jemović

University of Niš, Faculty of Economics, Trg kralja Aleksandra Ujedinitelja 11, 18000 Niš, Serbia

E-mail: mirjana.jemovic@eknfak.ni.ac.rs 
needs of future generations (United Nations General Assembly, 1987). As such, it includes three dimensions: economic, social and environmental, and emphasizes that economic and social progress is possible only with the simultaneous care of the environment. The importance of the concept of sustainable development is recognized at the global level, where the leading G-20 countries and influential international organizations (World Trade Organization, G-20 group, United Nations, etc.) identify sustainable development and environmental protection as priorities. The role of banks in this process is indisputable, bearing in mind that they are key players on the financial market in most financial systems. The integration of sustainability into business strategy, decision-making processes, business activities, risk management processes, as well as bank reporting systems, contributes to the sustainable development of the financial and overall economic system. The paper aims to look at the role of banks in achieving sustainable development goals, as well as the effects that environmental risks have on banks. The structure of the paper consists of three parts. The first will point out the alternative approaches of banks in the application of the concept of sustainability, both through the improvement of their internal processes and through the offer of "green" banking products. The impact of risks arising from the environment on banking operations and banking reporting specifics will be analyzed in the second part of the paper. In the last part of the paper, the challenges posed by environmental risk management to regulators, supervisors and banks themselves as regulated entities will be considered, as well as the efforts of supranational regulatory bodies to establish coordination of activities and measures in this field.

\section{FinANCE AND BANKIng Towards Sustainable DEVELOPMENT}

Modern economic systems must be accompanied by a functional ecological system. That is why environmental protection is an important precondition for doing business in any economic activity. Given the key role of banks in financing the economic activities of most financial systems, their role in achieving sustainable development goals is crucial. However, banks have begun to see the impact of their activities on the environment quite late, classifying themselves in the group of "clean" industries. In addition, they did not show initiative to influence the change of client behavior in the part of their responsibility towards environmental protection. Such an attitude was especially present in European banks. U.S. banks have shown a more proactive approach to environmental liability, especially since the enactment of the Comprehensive Environmental Response, Compensation and Liability Act (CERCLA) in 1980, which provided for the obligation of banks to bear the costs of environmental pollution of their customers. The special emphasis in American banks was on credit risks. European banks, on the other hand, initially had no direct environmental responsibility. Their more proactive approach began only during the 1990s, and was focused on the development of new environmentally friendly products (Jeucken \& Bouma, 2001, pp. 24-26). After that, the number of banks that apply environmental standards is constantly increasing.

\subsection{Institutional framework of sustainable finance and banking}

International organizations, agencies and institutions adopt programs and initiatives that provide guidelines to corporations and governments to integrate economic, social and environmental aspects. Although most of the initiatives appear in the form of 
recommendations and principles and are not fundamentally binding in nature, there is a positive relationship between states, corporations, financial institutions and investors. The first major initiative, the United Nations Framework Convention on Climate Change (UNFCCC), emerged during the 1992 World Summit in Rio de Janeiro, setting the framework for international cooperation in the fight against climate change and global warming. With the same goal, the Kyoto Protocol was adopted in Japan in 1997, which, unlike the Convention, is binding. Its application, solely in developed countries, has not contributed to the achievement of the set goal. For these reasons, an agreement on climate change management was adopted in Paris in 2015, which became legally binding for all countries.

With the first initiatives in the field of environmental protection, financial institutions have shown interest in engaging in this field. In their activities in the field of environmental protection and broader social responsibility, banks and other financial institutions have joined numerous initiatives, programs, agreements, among which the most important are shown in Figure1.

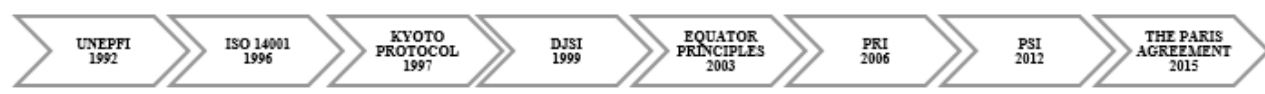

Fig. 1 The Evolution of Sustainable Finance Source: UNEP FI (2021)

The United Nations Environment Program Finance Initiative (UNEP FI) was launched in 1992 in order to establish a long-term partnership between UNEP and the international financial sector (banks, insurance companies and investors) from over 60 countries. The initiative envisages that environmental protection be an integral part of business activities and services of financial institutions, as well as that investment policy be directed towards environmentally sustainable projects. The positive attitude of financial institutions towards this initiative is evidenced by the fact that the initiative was supported by 13 banks, and that today more than 350 institutions - banks, insurance companies and investors, as well as more than 100 so-called supporting institutions, which contribute to sustainable financing within the financial system, support it. Along with UNEP FI, the Sustainable Stock Exchanges Initiative (SSEI) was launched in 2012, making an effort to establish a global platform for reviewing the stock market's contribution to sustainable development goals. Today, this initiative includes 106 stock exchanges listing 53,399 companies with a total market capitalization of 88,343,273 million US \$ (Sustainable Stock Exchange Initiative, 2021). In order to assess the contribution of stock exchanges to the goals of sustainable development, a database on the activities of stock exchanges in this field was formed, whereby the assessment is performed from the point of view of certain criteria, presented in Table 1.

Table 1 Criteria for the Sustainable Stock Exchange Database

\begin{tabular}{lcc}
\hline Criteria & \multicolumn{2}{c}{ Criteria fulfilment } \\
\hline Stock Exchange has a sustainable partner & Yes & No \\
Reporting about sustainability & Yes & No \\
ESG criteria as a listing rule & Yes & No \\
Has written ESG guidelines & Yes & No \\
Offers training regarding ESG & Yes & No \\
Has sustainability-related index & Yes & No \\
Has listing platform for sustainable bonds and SME & Yes & \\
\hline
\end{tabular}


Sustainability information is an integral part of individual stock market reports. Having in mind the mentioned criteria, it should be noted that some stock exchanges managed to meet all the criteria (China - Hong Kong Exchanges and Clearing Limited; India - Bombay Stock Exchange; Indonesia - Indonesia Stock Exchange; Luxembourg Bourse de Luxembourg; Peru - Bolsa de Valores de Lima) listing 9,144 companies with a market capitalization of $6,743,309$ million US \$. In addition, the number of stock exchanges undertaking an increasing number of activities in the field of sustainability is constantly increasing, which is clearly shown in the following presentation (Fig.2).

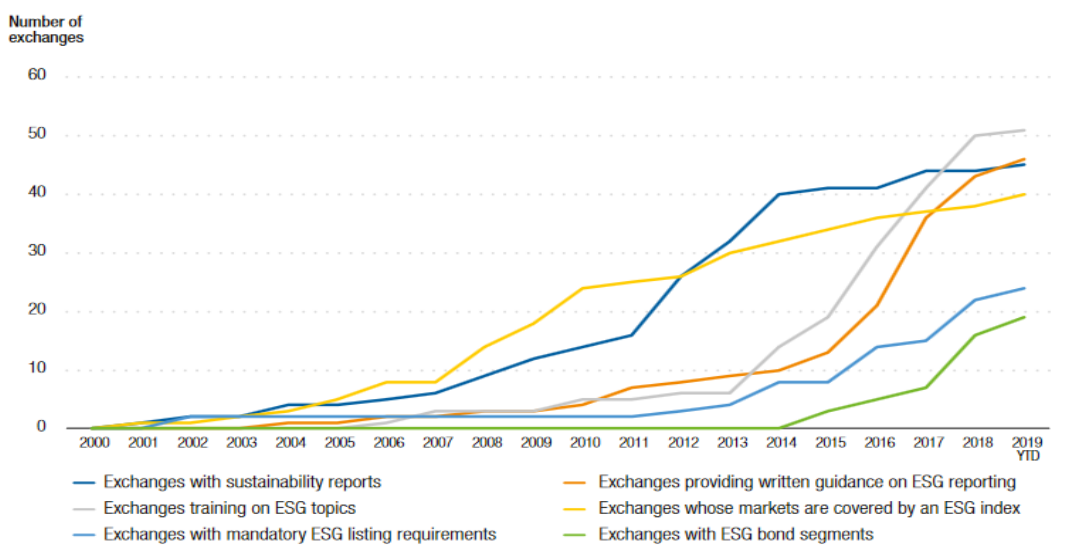

Fig. 2 Growth of stock exchange sustainability activities Source: SSE initiative and the World Federation of Exchanges (2019, p.10)

The development of The Dow Jones Sustainability Indices (DJSI) speaks in favor of the importance of environmental issues and raising the awareness of companies and numerous organizations about the need to incorporate them into their business. Created in 1999, this index includes companies from as many as 61 industries around the world that have achieved the best ESG results. The assessment includes a number of criteria, such as corporate governance, customer relations, environmental policies, working conditions and social initiatives. By type of construction, this index is weighted by free-float market capitalization. DJSI includes more than 3,500 international groups and, as such, is a good indicator for investors who prefer a "sustainable" investment portfolio (S\&P Dow Jones Indices: Dow Jones Sustainability Indices Methodology, 2021). In addition to DJSI, as many as 45 stock exchanges have developed their sustainability indices, which confirms the growing importance of sustainable finance for achieving sustainable development goals.

Among the numerous UN initiatives in the field of environmental responsibility and sustainable development, the Principles for Responsible Investment (PRI) stand out, which were adopted in 2006. Six principles have been formulated, the basis of which is to consider the impact of environmental and social factors on the investment process, and to incorporate the concept of sustainability into investment decision-making and investment processes. Since its establishment, the number of organizations that have signed these principles has been constantly growing (over 2,300). In addition, the Equatorial Principles adopted in 2003 are important, as a framework for environmental and social risk management, which can occur in project financing (Weber \& Acheta, 2016). The primary task of this 
framework is to provide minimum standards for due diligence and risk monitoring to enable the financing of only those projects that do not pose a risk to the environment and society. These principles have been adopted by 116 financial institutions in 37 countries, which otherwise finance most projects. Having in mind the positive institutional framework for the engagement of banks and other financial institutions in the field of achieving sustainable development goals, we will consider the approaches by which banks adopt the principles of sustainable development, the risks they face in this process, as well as the directions of further development of banks in conditions of their heightened environmental responsibilities.

\subsection{Banks' environmental responsibility approaches}

Modern economic systems must be accompanied by a functional ecological system. That is why environmental protection is an important precondition for doing business in any economic activity. Given the key role of banks in financing the economic activities of most financial systems, their role in achieving sustainable development goals is crucial. In this context, the responsibility of banks towards environmental protection has a dual nature: 1) internal, which implies the transformation of banks in the direction of their greater corporate eco-efficiency; and 2) external, which implies the development of banking products and services that contribute to sustainable development.

Eco-efficiency of banks: Banks belong to relatively clean industries. However, having in mind that this is a sector with a significant share in gross domestic product, its consumption of paper, energy, water is not negligible. Analyses conducted by banks in an attempt to "measure" the impact of banks on the environment, confirmed the significant impact of energy consumed by banks. In that sense, greater corporate eco-efficiency of banks implies efficient use of resources, introduction of new technologies, improvement of business processes, in order to ultimately achieve a positive impact of banks on the environment. For these reasons, many banks and other financial institutions have started using renewable energy sources (such as solar energy), use water and means of transport more rationally, reduce the use of paper, etc. (Jeucken \& Bouma, 2001, pp. 29-30). In addition to the positive impact on the environment, this practice contributes to cost efficiency, long-term performance growth and improving the bank's image (Nizam et al., 2019).

Development of "green" banking products and services: Although not considered direct polluters, banks indirectly bear part of the responsibility for environmental pollution when they place money with clients engaged in activities that have a direct impact on environmental pollution. By approving green banking products and financing environmentally sustainable projects, banks contribute to their own clients becoming part of the "sustainability chain". Although the implementation of the concept of sustainability is not binding, the banking sector provides significant support to the implementation of the concept of sustainability and raising awareness of the importance of environmental protection. An increasing number of banks are adopting the concept of green banking, and strive to provide products and services to customers who take into account the consequences of their actions on the environment. This is not a one-way impact, given that the environmental practice of users of banking services ultimately affects the banking business. The impact of environmental risks on client operations, through approved bank loans and other bank products, affects the bank's operations. 
The practice of "greening" banking products and services began first in the payment system, primarily in the payment card segment. Given that card payment has an upward trend, the contribution to the goals of sustainable development through this banking product is significant. Specifically, during the transaction, a certain percentage $(0.1-0.5 \%)$ of the value of each purchase or transaction is transferred to non-governmental organizations for environmental protection or a special environmental fund. Prominent examples are: the World Nature Card created by the Swedish bank Föreningssparbanken and the WWF Visa Affinity Card created by the Royal Bank of Canada, where as much as $0.5 \%$ of the transaction value is transferred to the account of the NGO for animal and environmental protection (The World Wide Fund for Nature, WWF); HSBC Visa Card, where $0.1 \%$ of the purchase amount is transferred to the HSBC Green Roof for Schools program with each purchase; the Environmental Defense Platinum MasterCard created by the American bank Citigroup, etc. (Jeucken, 2001). In the area of savings accounts, directing funds to environmental funds is still the practice of individual banks. Thus, the VSB Panda Certificate stands out, within which the Fortis Group pays a fixed amount to WWF after the certificate is sold. In addition, ASN Bank and the Triodos Bank in The Netherlands use raised funds on savings accounts for placements in sustainable projects. In addition, investment funds specializing in investment in sustainable projects are formed, aimed at protecting the environment in general (Environmental Growth Fund), or a specific segment of sustainability, e.g. sustainable energy (Wind Fund, Solar Investment Fund).

When it comes to loans, an increasing number of banks offer loans that put the environmental dimension in the forefront. These are "green" car and mortgage loans, loans for energy efficiency, loans for small and medium enterprises that invest in sustainable development. In order to motivate customers to buy cars with high fuel efficiency, this type of loan is offered at lower interest rates compared to those for buying conventional cars. In addition, a lower interest rate is charged when taking a loan for the purchase of energy efficient real estate, as well as for the reconstruction and adaptation of homes. In addition to lower loan prices, clients reduce housing costs, achieve higher energy efficiency of the home, save energy, etc.

Previous banking products are intended primarily for households. In addition, banks seek to offer "green" banking products to the corporate sector. In order to encourage investments of small and medium enterprises in sustainable projects, banks form their own funds to approve loans on more favorable terms to companies that invest in sustainable projects. In the European Union, this process is supported by the European Investment Fund, and the number of banks that can participate in this program is limited. For priority projects, the Fund participates with as much as 50 percent in the total approved loan. In addition to lending, banks, through the investment banking segment, provide advisory and securities placement services to organizations that consider the effects of their business on the environment. In the area of advisory services, banks specialize in providing information to clients on sustainable projects, sustainable technologies, tax and legislative framework governing this matter. To this end, banks issue a number of brochures and reports with useful guidance on various aspects of adopting the concept of environmental responsibility. In addition, banks transfer part of the risk to investors through the mechanism of securitization of "green" loans. This process is known as eco-securitization. A prominent example is Forest Bond, created to finance the large and complex reconstruction of the Panama Canal, on the basis of which a twenty-five-year bond was created, whose buyers are entities that use this waterway. Catastrophe bonds (Cat Bonds), created to protect insurance companies from catastrophic 
risks, by transferring them to investors, with the support of investment banks, also stand out (UNEP FI, 2007). In addition, specific financial derivatives have been created, primarily to protect companies from risks that may be caused by adverse weather conditions.

\section{ENVIRONMENTAL RISKS IN BANKING}

Various internal and external factors are putting pressure on banks to increase their role in environmental risk management and environmentally sustainable development. Banks are in a position to play a significant role in promoting sustainability, as bank loans continue to be the dominant source of funding for non-financial companies. For example, in the EU, the share of bank loans in the total debt of these companies was $82 \%$ (EBF, 2017, p. 7).

\subsection{Integration of sustainability into banks' lending activity}

Sustainable finance for banks is a source of new opportunities, but on the other hand, banks are more and more concerned about their exposure to environmental risk. The EY/Institute of International Finance (IIF) risk survey indicates that not only regulators are aware of growing environmental risks, but also that banks consider them to be key risks they will face in the coming years (EY/IIF 2019, p. 8). Banks have begun to integrate sustainability into risk management processes, green banking product design, and long-term strategies (BGLN, 2020, p. 1), but the integration of sustainability has been hampered by a lack of appropriate standards, relevant indicators, and the sharing of best practices (BGLN, 2020 , p. 6). To overcome these limitations, the importance of regulators which could help coordinate and exchange information has been recognized. This is indicated by the establishment of the Network of Central Banks and Supervisors for Greening the Financial System, which now consists of 89 members representing central banks from countries around the world.

When integrating sustainability in the activity of banks, two approaches are distinguished: (a) a risk-based approach and (b) a values-based approach.

Table 2 Integration of sustainability

\begin{tabular}{ll}
\hline Sustainable Finance Typology & Bank loans \\
\hline Sustainable Finance 1.0 & Exclusion \\
Sustainable Finance 2.0 & ESG integration \\
Sustainable Finance 3.0 & Impact lending, microfinance \\
\hline \multicolumn{2}{c}{ Source: Schoenmaker \& Schramade $(2019$, p. 30$)$}
\end{tabular}

As seen in Table 2, the risk-based approach involves excluding loan applications from companies involved in environmentally risky activities, and then including the ESG principle in the lending decision-making process. A step further in the integration of sustainability is a value-based approach that includes mission, strategy, publicly available information on ESG activities, impact of products and services etc.

Natural disasters and climate change bring high costs, the impact of which can undermine financial stability of both individual banks and the financial system as a whole 
(NGFS 2020a, p.4). Integration of sustainability into lending activity can reduce the credit risk to which banks are exposed (Weber et al., 2015). Some empirical research found that banks with higher share of green loans to the total loan portfolio have lower non-performing loan ratio - (NPL) (Cui et al., 2018). The implementation of the concept of sustainability in lending activity should contribute to greater resilience of banks, but there is a danger that banks that base lending decisions on detailed environmental analysis may be at a disadvantage compared to non-banking competitors that provide alternative sources of financing.

Research by the European Banking Authority shows that - banks incorporate sustainability into their broader business strategy (around 95\% of banks) (Coleton et al., 2020, p.11) and they see climate risk as a potential material risk (around $60 \%$ of banks) (Coleton et al., 2020, p.20). The majority of surveyed banks (77\%) take into account the direct and indirect impact of activities that they finance (Coleton et al., 2020, p. 14). Direct impact that a bank has on the environment and society stems from its use of natural resources in doing business, while its indirect impact comes from its lending activity and projects it finances. Although they believe that risk management is a key mechanism for shifting capital from unsustainable activities to more sustainable investment, they do not see sustainability as something at the very core of risk management, which is a paradox that leaves room for regulators and supervisors (Coleton et al., 2020, p. 16).

In order to understand the drivers, practices and challenges of sustainable investment and financing, the OECD Secretariat interviewed risk managers from the largest OECD banks (OECD, 2020). According to the answers received, the leading driver of the integration of the ESG into the lending practice was the demand from investors (OECD, p. 121). Otherwise, investors are putting pressure on banks to get involved in managing and reporting on ESG risks. The OECD survey showed that almost all major banks have environmental and social policies and that most policies cover the practice of corporate lending (OECD, 2020, p. 126) and "screen their lending portfolios against specific ESG risks", but it was noticed that there are differences in the degree of implementation of ESG due diligence and that more attention is paid to environmental risks for project financing transactions (OECD, 2020, p.127).

\subsection{Types of environmental risks for the bank}

On the one hand, the exposure of banking clients to environmental risks is a source of opportunities for banks because it creates demand for products such as bank guarantees, green loans or environmental insurance products (Jeucken, 2001, p. 120). On the other hand, environmental risks for a bank are mainly the result of the environmental risks to which its borrower is exposed (Jeucken, 2001, p. 120).

The term "environmental risks" encompasses environmental-related risks and climaterelated risks. Environment-related risks include risks arising from a bank's exposure "to activities that could potentially cause or be affected by environmental degradation" (NGSF, 2020 b, p. 4) (such as soil, air and water pollution, deforestation, etc.) Climate-related risks refer to the risks posed by banks' exposure to "physical or transitional risks caused by or related to climate change" (NGSF, 2020b, p. 4). 
Table 3 Sources of environmental risks

\begin{tabular}{ll}
\hline Physical Risks & Climate-related financial risks on the banking sector \\
\hline Extreme weather events & - Higher expected default by climate vulnerable \\
(e.g., winter storms, heat waves, floods) & sectors (e.g., agriculture and tourism) \\
$\begin{array}{l}\text { Ecosystem pollution } \\
\text { Sea-level rise }\end{array}$ & - Lower property values in coastal areas \\
Water scarcity & - Sovereigns due to extreme weather events \\
Deforestation/desertification & - Relocation of headquarters and data centers \\
\hline Transition Risks & Climate-related financial risks on the banking sector \\
\hline $\begin{array}{l}\text { Public policy change (e.g., carbon pricing, } \\
\text { pollution control regulations, resource }\end{array}$ & - Declining collateral value \\
conservation regulations) & - Stranded assets \\
Technological changes (e.g. clean energy & - Higher expected default by carbon intensive \\
technologies, energy saving technologies) & - Hectors \\
$\begin{array}{l}\text { Shifting sentiment (e.g., changes in consumer } \\
\text { preference for certain products, changes in }\end{array}$ & - Higher transaction costs due to weakened \\
investor sentiment on certain asset classes) & - Higher reputational risks by investing in carbon- \\
$\begin{array}{l}\text { Disruptive business models (new ways to run } \\
\text { businesses that can rapidly gain market shares }\end{array}$ & intensive sectors \\
from traditional businesses) &
\end{tabular}

The sources of environmental risks are diverse, so these risks can be divided into two groups: physical risks that arise from weather-related events and transition risks that arise from the transition to a lower-carbon economy, as shown in Table 3.

The borrower's failure to address environmental issues effectively may jeopardize its business, as well as the bank that finances it. The bank may have to deal with: (a) delays in loan repayment or loan write-offs, (b) loss of collateral value on liquidation, and (c) loss of reputation and impairment of the brand.

\subsection{Transformations of environmental risk into credit risk}

Banks may be exposed to credit risk due to the compromised ability of the client to repay the loan. A bank is exposed to credit risk when a borrower is unwilling and/or unable to meet its contractual obligations due to environmental factors. Here, it is important to assess the client's financial ability to finance its environmental risks and to invest in preventive environmental management (Jeucken, 2001,p. 129).

Legal problems in the field of environmental protection faced by the borrower may jeopardize the continuity of its business. Problems in obtaining and retaining environmental permits (emission/discharge permits) or the need for the company to invest additional funds to obtain permits or comply with the regulations may have a negative impact on the business continuity of the company and its financial position. This may reduce the repayment capacity of the loan or lead to the termination of the bank's credit relationship with such a borrower. It is important for the bank to be aware of the client's liability for damage to the environment (environmental accidents or regulatory fines for violating the environmental permit or its expiration) as well as the client's financial capacity and reserves to cover these risks. There may also be the borrower's liability for environmental damage that will occur elsewhere in the production chain, i.e. the so-called "sticky 
liability" (for example for substances embedded in a product) with which banks must be familiar (Jeucken, 2001, p. 125).

As shown in Table 3, one form of environmental risk is transition risk resulting from adaptation to a low-carbon economy and climate change, including changes in environmental policies and regulations, changes in technology, and changes in public mood and social preferences. This type of risk can affect the value of banks' loan portfolios or the value of financial assets in the affected sectors. For example, changes in the field of competition and consumer demand can lead to the loss of a part of the borrower's market and jeopardize its loan repayment capacity. More environmentally responsible competitors and their products pose a risk to a company that does not have such environmentally friendly producers. Consumers themselves may also demand more environmentally friendly products or production processes, and a problem may arise if the borrower is unable to meet the resulting changes in consumer demand and expectations.

Physical risks do not originate from the borrower's company and include several sources of risks: extreme weather events, climate change and environmental accidents that may lead to serious water and land pollution (NGFS, 2000b, p.5). For example, extreme weather events may disrupt business activity of -borrower and thus affect the ability to repay the loan, climate change and soil or water pollution can cause excessive costs for agriculture.

The materialization of environmental risk for the bank may also occur due to the fall in the value of the borrower's collateral. Security is an important factor in bank lending. The role of collateral can be played by the registered assets of the borrowing company (land or buildings) or inventories. Environmental factors can negatively affect the value of a particular asset of a borrower that is pledged as collateral (NGF, 2020). For example, the value of pledged land may fall due to pollution, a high-value machine that pollutes the environment may be worthless when sold, the value of pledged stock may fall due to lack of demand in the case of environmentally unacceptable products and the like.

Mortgaging gives the bank the right to sell the mortgaged real estate if the borrower does not fulfill its obligations to the bank. In the event that a bank becomes the owner of a pledged real estate, it may be exposed to the risk of not only a decline in value but also the occurrence of negative collateral value. The bank is exposed to liability risk arising from the client's legal obligations. This includes fines, costs for resolving third party claims for damages due to negligence in the client's environmental risk management and pollution clean-up. For example, a bank may be liable as the owner when contaminated land that is collateral has to be rehabilitated and cleared before sale (Tarna, 2001, p. 159- 160).

\subsection{Negative impact of environmental risk on the bank's reputation}

The bank is exposed to reputational risk due to potentially negative publicity associated with the borrower's poor environmental practices. With the increase of environmental awareness and attention focused on the issue of protection of the environment, the impact of environmental risk on the bank's reputation has become important because it affects not only specific loans but the entire loan portfolio and all other areas of the bank's business. Similarly, negative publicity that a bank gains on a particular local market can damage its reputation and negatively affect its business as a whole. However, this type of environmental risk is difficult to assess financially. Negative publicity damages the brand values and the image of the financial institution in the media, the public, the financial and business 
community. The main negative consequence of damaged reputation is the abandonment of the bank by existing clients and the inability to acquire new clients.

Environmental risks to a bank's reputation are more pronounced in project financing (Case, 1999, p. 146), in cases of large infrastructure investments (such as roads and railways) and new technologies (Jeucken, 2001, p. 139). The negative public attention that is focused on companies and projects that pollute the environment does not bypass the institutions that finance them. Non-governmental organizations (NGOs) closely monitor banks in this regard. According to the organization that globally monitors the activities of NGOs, the number of campaigns aimed at banks that provide financial support to environmentally unacceptable projects is significantly increasing (OECD, 2020, p. 122). The NGOs campaigns (naming and shaming bad practices, inviting target bank clients to close accounts en masse, and similar campaigns) target the banks financing fossil fuel projects and supporting fossil fuel companies through corporate lending, issuing of bonds and share and bond holdings (Schücking et al., 2011).

This imposes the need for the bank to seriously examine potential borrowers or projects from the aspect of environmental risks. It should be borne in mind (Jeucken, 2001, p. 142): (a) that simply linking the bank to the detrimental impacts of the company or project on the environment is sufficient to create reputational risk (the degree of bank participation in the project is generally irrelevant, it can be only advisory services), (b) that there are geographical and cultural differences due to which the local population does not see the project as harmful to the environment, but clients in developed countries consider it environmentally unacceptable, which can damage the bank's reputation (e.g. the positive economic effects of the project are emphasized in developing countries), (c) that, while an isolated problem can be forgotten, a number of problems can seriously damage a bank's reputation, (d) that the larger projects are more likely to have adverse impact on the environment and/or to attract the attention of NGOs and (e) that project funders may underestimate risk when it is not measurable.

\subsection{Environmental risk assessment}

Banks strive to manage environmental risks. This includes linking the risk and the probability of negative impacts and the consequences of the occurrence of a risky event. Environmental risk becomes uncertainty when its probability and cost cannot be predicted and calculated. The bank assumes those risks for which the probability of loss can be predicted with a certain degree of certainty. Determining the exposure of banking institutions to environmental risk is not always easy. Credit exposure to "brown assets" is easier to determine (for example, exposure to key players in the fossil fuel industry) but it is far more complex to assess exposure to climate change (BGLN, 2020, p. 6-7)).

To reduce environmental risk exposure, banks must understand the potential environmental risks and their implications for the potential borrower's business. This requires proactive identification, assessment and management of environmental risks before they become significant or result in a negative outcome for the borrower and make it impossible to meet its financial obligations to the bank. Risk identification refers to the strategic assessment of environmental factors that may result in financial risks (NGSF, 2020b, p. 11). The extent of the bank's exposure to these risks is then determined (e.g. 10\% of the loan is exposed to risks). Risk assessment refers to "estimating the probability and magnitude of financial losses that may arise from these risks" (NGSF, 2020b, p. 12). Banks can mitigate environmental risks by 
taking risk reduction actions such as refusing a loan application from companies involved in environmentally risky activities, adjusting the interest rate or maturity of the loan to environmental risk or inserting specific clauses in loan agreements (Jeucken, 2001, p. 119).

For an effective environmental risk assessment, it is necessary for the bank to have information on the environmental sensitivity of the companies it finances. The bank may use its own resources or external expertise. Some of the possible sources of information on companies' environmental risk exposure are (Jeucken, 2001, p. 145): (a) standardized lists of questions (regarding compliance, own ESG initiatives, records of previous incidents, etc.) (b) information obtained from specialized agencies (credit rating agencies - are integrating ESG consideration into credit rating (Beeching et, al., p. 5) (c) direct contact with a potential borrower for risk assessment, (d) environmental reports, (e) permits and other government sources, (f) policy documents issued by the government; (g) past experience or experience of other banks, etc.

One of the methods for analyzing environmental risks in banks is the assessment of possible environmental scenarios. Scenario analysis could be used to determine the financial impact of climate-related risks (transition and physical risks) on banks (NGFS, 2020 b, p. 3). Scenario analysis may include the following steps (Repetto \& Austin, 2001, p. 281): (a) defining the sector, (b) identifying prominent future environmental issues for the sector, (c) identifying scenarios, (d) assigning probabilities to the scenarios, (e) assessing the exposure of individual companies, (f) assessing the financial impact of the scenario and $(\mathrm{g})$ constructing an overall measure of the expected impact and risk.

Since various sectors may be more or less sensitive to the environment, many banks begin an environmental risk assessment with an analysis of the sector in which a particular company operates. Sectors differ in terms of environmental sensitivity. Environmental sensitivity means "that products from the production process itself and the emissions of the production process can be regarded as actually or potentially threatening for the environment" (Jeucken, 2001, p. 120) Particularly environmentally sensitive sectors include agriculture, fishing, mining and the like. Environmental risks are especially pronounced when looking at individual industries. Environmentally sensitive industries include oil refineries, metal production, textile industry, livestock, etc. Banks are exposed to greater risk when investing in companies operating in environmentally sensitive industries.

Environmental risks to which a bank is exposed also depend on the size of the company it lends to. These risks are more pronounced when it comes to small and medium-sized enterprises that approach environmental issues ad hoc, do not have specialized knowledge for solving problems in the field of environmental protection and only strive to comply with their regulations. Large companies have a greater opportunity to hire or train staff to deal with environmental issues, approach environmental issues systematically, have specialized knowledge of relevant legislation or technological and organizational solutions that they can use to innovate products that meet society's sustainability requirements (Jeucken, 2001, p. 122)

\section{REGULATORY APPROACHES FOR ENVIRONMENTAL RISK MANAGEMENT IN BANKING}

Recognizing the impact of environmental risks on banking operations, central banks and supervisors are taking a number of initiatives to reduce the negative impact of these risks on banking operations, and, thus, financial stability. At the international level, in 2017, the Network for Greening the Financial System (NGFS) was formed as a group of 
central banks and supervisors, within which experiences are exchanged and non-binding principles are adopted to guide banks towards financing sustainable projects. In February 2020, the Basel Committee formed a high-level Task Force on Climate-Related Financial Risks (TFCR), in order to monitor the risks that climate change may have for banks. In the initial stages of its work, the TFCR organized a forum for the exchange of regulatory and supervisory practices of member states in the field of climate change risk management. Most participants supported the need to include these risks in the monitoring list, bearing in mind that they may have negative implications for banking operations. However, monitoring and managing these risks are significantly hampered by the lack of a unified methodology for measuring and calculating their impact on the stability of the banking sector, which makes it difficult to compare banks within the same, but also between different banking systems.

At this stage, most countries are raising awareness of the importance of taking these risks into account, but a prudential framework for including these risks in the capital adequacy calculation has not yet been established. Although the focus of regulatory and supervisory bodies, as well as supranational organizations, after the outbreak of the COVID-19 pandemic shifted to considering the impact of the pandemic on financial stability, the pandemic reaffirmed the importance of implementing ESG principles in banking operations. TFCR coordinates its work with the Network for Greening the Financial System (NGFS), the Financial Stability Board and other international organizations that set standards in this area, all with the aim of global coordination of issues related to environmental risks, especially those which are related to climate change and global warming.

In addition to initiatives at the supranational and national level, there are also initiatives at the level of individual banks. Specifically, an increasing number of banks include these risks in risk management systems, developing special instruments and methods for their coverage and measurement. An increasing number of banks report these risks in their reports, although they are not required to do so by the current regulatory framework. Most countries seek to develop approaches to measuring and managing the risks posed by climate change and other environmental impacts, as well as to look at the mechanisms by which the effects of these risks affect banking operations. In this regard, most countries believe that the existing prudential framework should be adapted to include environmental risks in the list of risks, while a minority believe that these risks should be integrated into the existing risk classification within the appropriate risk group (e.g. credit risk, operational risk etc.). For example, banks are expected to consider environmental risks when assessing the creditworthiness of borrowers, both in the phases of the loan approval process and later during the monitoring of the loan portfolio. The Prudential Regulation Authority (PRA) requires banks to consider this risk when calculating the capital adequacy ratio. Given that Pillar 2 of the Basel Framework provides for the possibility of internal assessment of capital adequacy, banks are left with the possibility to cover risks that are not fully covered by Pillar 1, which creates a basis for including environmental risks, especially climate change. In addition, in order to strengthen the market discipline of banks in this field, under Pillar 3, it is possible to provide for the obligation to publish relevant information on banks' exposure to environmental and social risks, especially in the case of large banks (BCBS, 2020). 


\section{CONCLUSION}

Banks introduce the concept of social responsibility into their operations and implement numerous projects that significantly contribute to the community. Banks create green banking products and services and act as sources of financing for green projects. In addition, in the current environment, banks are working to raise awareness of the importance of sustainability and environmental protection both among their employees and in the community in which they operate. A comprehensive approach to environmental management involves establishing an internal environmental system (online services, reducing energy consumption, raising employee awareness, etc.), managing environmental risks associated with lending operations (credit portfolio environmental risk assessment) and promoting sustainable financing through creating green banking products and services.

In general, companies are increasingly being judged on the basis of their attitude towards the environment - customers today are undoubtedly better informed, more environmentally conscious and more sensitive. There are social expectations that the banking sector should also be more careful about environmental risks. In addition to economic indicators, banks are introducing sustainability as an important criterion for business cooperation with companies. Increased environmental risk may result in impaired ability of the borrower to repay a loan. Banks are therefore intensifying the inclusion of the sustainability element when deciding on loan approvals and developing procedures for assessing the risks associated with environmental damage that can be caused by loan beneficiaries. However, banks face ongoing challenges in the process of integrating sustainability into risk management frameworks due to the new and complex nature of risk, lack of historical data, lack of appropriate standards and relevant indicators for measuring environmental risk. The development of an adequate framework for measuring and monitoring environmental risk would contribute to the public declaration of banks as socially responsible institutions not only for marketing purposes, but also accompanied by appropriate actions in the field of sustainability. Sustainable banking includes environmental risk management and credit support to businesses that make positive impact on the environment. The transformation of banking from traditional, predominantly profit-oriented, to sustainable banking implies the creation of sustainable values for the banks themselves, but also for society as a whole.

\section{REFERENCES}

BCBS (2020). Climate-related financial risks: A survey on current initiatives. Bank for International Settlements.

BGLN (2020). Sustainability and purpose in banking, Bank Governance Leadership Network ViewPoints. Retrieved from https://assets.ey.com/content/dam/ey-sites/ey-com/en_gl/topics/banking-and-capital-markets/eybgln-viewpoints-sustainability-and-purpose.pdf

Beeching, A., Nuzzo, C. \& Adams, T. (2017). Shifting perceptions: ESG, credit risk and ratings - Part 1: The state of play. UNEP Inquiry, PRI， UN Global Compact UNEP Finance Initiative. Retrieved from: http://unepinquiry.org/ wp-content/uploads/2017/07/PRI_Shifting-Perceptions_The-state-of-play.pdf

Case, P. (1999). Environmental Risk Management and Corporate Lending: A Global Perspective. Cambridge: Woodhead.

Coleton, A, Font Brucart, M, Gutierrez, P, Le Tennier, F., \& Moor, C. (2020). N. 6 - January 2020 Sustainable finance Market practices. EBA Staff Papers Series DZ-AH-19-003-EN-N. European Banking Authority. Retrieved from https://www.eba.europa.eu/sites/default/documents/files/document_library/Sustainable\%20finance $\% 20$ Market\%20practices.pdf

Cui, Y. J., Geobey, S., Weber, O., \& Lin, H. Y. (2018) The impact of green lending on credit risk in China. Sustainability, 10(6). http://dx.doi.org/10.3390/su10062008 
ECB (2020). Guide on climate-related and environmental risks: Supervisory expectations relating to risk management and disclosure. Retrieved from https://www.bankingsupervision.europa.eu/legalframework/publiccons/pdf/ climate-related_risks/ssm.202005_draft_guide_on_climate-related_and_environmental_risks.en.pdf

EBF (2017). Towards a Green Finance Framework. European Banking Federation, Retrieved from https://www.ebf.eu/wp-content/uploads/2017/09/Geen-finance-complete.pdf

EY/IIF (2020). An endurance course: surviving and thriving through 10 major risks over the next decade, Tenth annual EY/IIF global bank risk management survey. London: EYGM Limited.

Jeucken, M. (2001). Sustainable finance and banking: the financial sector and the future of the planet. London: Earthscan Publications Ltd.

Jeucken, M., \& Bouma, J. (2001). The changing environment of banks. In: Bouma, J., Jeucken, M. \& Klinkers, L. (Eds.), Sustainable banking: The greening of finance (pp. 24-38). UK: Greenleaf Publishing Limited.

NGFS (2020a) The Macroeconomic and Financial Stability Impacts of Climate Change Research Priorities. June 2020. Retrieved from https://www.ngfs.net/sites/default/files/medias/documents/ngfs_research_priorities_final.pdf

NGFS (2020b). Overview of Environmental Risk Analysis by Financial Institutions Network for Greening the Financial System. Technical document, September 2020. Retrieved from https://www.ngfs.net/sites/default/ files/medias/documents/overview_of_environmental_risk_analysis_by_financial_institutions.pdf

Nizam, E., Ng, A., Dewandaru, G., Nagayev, R., \& Nkoba, M. (2019). The impact of social and environmental sustainability on financial performance: A global analysis of the banking sector. Journal of Multinational Financial Management, 49, 35-53. https://doi.org/10.1016/j.mulfin.2019.01.002

OECD (2020). OECD Business and Finance Outlook 2020: Sustainable and Resilient Finance. Paris: OECD Publishing.

Park, H., \& Kim, D. J. (2020). Transition towards green banking: role of financial regulators and financial institutions. Journal of Sustainability and Social Responsibility, 5(5). https://doi.org/10.1186/s41180-020-00034-3

Repetto, R., \& Austin, D. (2001). Estimating the financial effects of companies environmental performance and exposure, in: JJ Bouma, MHA Jeucken and L KI, Sustainble Banking - The Greening of Finance, pp. 280 294, Greenleaf, Sheffield

Schoenmaker, D., \& Schramade, W. (2019). Principles of Sustainable Finance. Oxford University Press. Retrived from https://ssrn.com/abstract=3282699

Schücking, H., Kroll, L., Louvel, Y., \& Richter, R. (2011). Bankrolling climate change - A Look into the Portfolios of the World's Largest Banks. Retrieved from: https://www.banktrack.org/download/bankrolling_climate_change/ climatekillerbanks_final_0.pdf

S\&P Dow Jones Indices: Dow Jones Sustainability Indices Methodology (2021). Retrieved from: https://www.spglobal.com/spdji/en/documents/methodologies/methodology-dj-sustainability-indices.pdf, Accessed on: 3 April 2021.

SSE initiative and the World Federation of Exchanges. (2019). How exchanges can embed sustainability within their operations: A blueprint to advance action.

Sustainable Stock Exchange Initiative. (2021). Retrieved from: https://sseinitiative.org/exchanges-filter-search/

Tarna, K. (1999). Reporting on the Environment: Current Practice in the Financial Services Sector, in: JJ Bouma, MHA Jeucken and L KI, Sustainble Banking - The Greening of Finance, pp. 280 - 294, Greenleaf, Sheffield.

UNEP FI (2007). Green Financial Products \& Services: Current Trends and Future Opportunities in North America. Retrieved from https://www.unepfi.org/fileadmin/documents/greenprods_01.pdf

UNEP FI (2021). Retrieved from: https://www.unepfi.org/news/25th-anniversary/timeline/

United Nations General Assembly (1987). Report of the world commission on environment and development: Our common future. Oslo, Norway: United Nations General Assembly, Development and International Cooperation: Environment.

Weber, O., \& Acheta, E. (2016). The Equator Principles: Do they make banks more sustainable?. Inquiry working paper, 05

Weber, O., Hoque, A., \& Islam, M. A. (2015). Incorporating environmental criteria into credit risk management in Bangladeshi banks. Journal of Sustainable Finance \& Investment, 5(1-2), 1-15. 


\section{ODRŽIVE FINANSIJE I BANKARSTVO: IZAZOV ZA REGULATORE I SISTEM UPRAVLJANJA RIZICIMA}

Ključna pozicija banaka u finansijskom sektoru, kao i njihova nesporna uloga u finansiranju privrednog razvoja uslovili su potrebu sagledavanja njihovog uticaja na životnu sredinu. Implementacija koncepta održivosti u bankarsko poslovanje uslovila je transformaciju banaka u pravcu njihove veće korporativne eko-efikasnosti $i$ razvoja bankarskih proizvoda i usluga koji doprinose održivom razvoju. Održive finansije za banke predstavljaju izvor novih mogućnosti, ali sa druge strane raste zabrinutost banaka zbog izloženosti ekološkom riziku. Prepoznajući uticaj ekoloških rizika na poslovanje banaka, centralne banke i organi supervizije preduzimaju brojne incijative kako bi umanjili negativan uticaj tih rizika na poslovanje banaka, a time i finansijsku stabilnost. Rad ima za cilj da ukaže na izazove koje je održivo bankarstvo stavilo pred regulatore $i$ sistem upravljanja rizicima.

Ključne reči: održivo bankarstvo, ekološki rizici, regulacija 